\section{Determination of TNF- $\alpha$ Gene Polymorphisms on Skeletal Pattern in Class II Malocclusion}

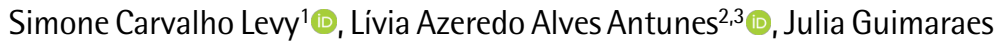
Barcellos de Abreu ${ }^{3}$, Jullia Assis da Silva Nascimento ${ }^{3}$, Ana Carolina Kuntz ${ }^{3}$, Walter Luis Soares Fialho ${ }^{4}$, Amanda Silva Rodrigues ${ }^{1}$, Ellen Cardoso Teixeira ${ }^{4}$, José de Albuquerque Calasans-Maia ${ }^{2}$, Marcelo Calvo de Araújo ${ }^{5}$, Erika C. Küchler $^{6}$, Leonardo Santos Antunes ${ }^{2,3}$ (D)

Bone development and growth is a non-going, life-long process, varying greatly among individuals and much of this variation could be modulated by genetic factors. The purpose of this study was to evaluate the association between the polymorphisms in the TNF- $\alpha$ gene and skeletal class II malocclusion. Single nucleotide polymorphisms in $T N F-\alpha$ (rs1799724; rs1800629) gene were studied in 79 skeletal class II malocclusion and 102 skeletal class I malocclusion subjects from Straight Wire Group of Studies on Orthodontics and Functional Orthopedics for Maxillary from Rio de Janeiro, Brazil. The Genotyping of these selected polymorphisms was carried out by TaqMan real-time PCR using genomic DNA extracted from buccal cells. All allele and genotype frequencies were compared between the groups using the PLINK ${ }^{\circledR}$ software in a free, in a dominant and in a recessive model using a chi-square test $(p \leq 0.05)$. There was no significant association of TNF- $\alpha$ (rs1799724; rs1800629) genotype and allele distribution with skeletal class II malocclusion. Regardless of the dominant or recessive genetic model, the preferential genotype associations for rs1799724 and rs1800629 was insignificant. In conclusion, no evidence of association is apparent between genetic polymorphisms involving TNF- $\alpha$ and skeletal class II malocclusion or the position of the maxilla and mandible in the postero-anterior direction.
'Postgraduate Program, School of Dentistry, UFF - Universidade Federal Fluminense, Niterói, RJ, Brazil ${ }^{2}$ Department of Specific Formation, School of Dentistry, UFF Universidade Federal Fluminense, Nova Friburgo, RJ, Brazil ${ }^{3}$ Clinical Research Unit, UFF - Universidade Federal Fluminense, Niterói, RJ, Brazil ${ }^{4}$ School of Dentistry, UFF Universidade Federal Fluminense, Nova Friburgo, RJ, Brazil ${ }^{5}$ Smile Graduate School and Clinic, Niterói, RJ, Brazil ${ }^{6}$ Department of Pediatric Dentistry, School of Dentistry of Ribeirão Preto, USP - Universidade de São Paulo, Ribeirão Preto, SP, Brazil

Correspondence: Dr. Leonardo Santos Antunes, Rua Doutor Silvio Henrique Braune, 22, 28625-650 Nova Friburgo, RJ, Brasil. Tel: +55-22-25287168. e-mail: leonardoantunes@id.uff.br .

Key Words: malocclusion, genetics, polymorphism, TNF- $\alpha$.

\section{Introduction}

The continuous growth begins in the pre-natal period and continues in the post-natal period. It seems to be more genetically controlled than environmentally affected (1). The skull base plays an important role in the growth of maxilla and mandible and in the relationship between them. Therefore, changes in both skull base angle and anterior and posterior lengths can cause imbalances in facial growth and consequently in occlusion (2). Changes in the craniofacial morphology are the origin of the most severe malocclusions, with those affecting morphology and mandibular size contributing more to the majority of malocclusions than the maxillary variations. (3)

ANB angle has been often used to assess sagittal changes present in Class II malocclusions $(4,5)$. Class II malocclusions can result from the anterior displacement of the maxilla or maxillary alveolar process; small mandible or lower teeth posteriorly positioned in their base; posterior position of the temporomandibular joint; and any combination of the above-mentioned factors (6)

Few observations postulated that the etiology of Skeletal Class II malocclusion is multifactorial, in which both genetic and environmental factors play a role in the development of the alteration. Studies of this condition demonstrated that it is heritable and is consistent with a polygenic mode of inheritance. A polygenic model implies that a number of genes with small additive effects provide genetic predisposition to the phenotypic expression (7)

Skeletal growth is maintained by a balance between cells which resorb bone (osteoclasts) and cells which form bone (osteoblasts). Bone development and grow this anongoing, life-long process (8). Until recently, the molecular nature of this regulation was poorly understood. However, recent investigations identified members of the TNF- $\alpha$ family of (tumor necrosis factor) and their receptors, which are essential regulators of osteoclastogenesis (9)

The RANKL/RANK signaling regulates the formation of osteoclasts, including physiological bone modeling and re-modeling and a variety of pathological conditions characterized by an increase of bone turnover. $O P G$ protects the bone from excessive resorption through binding to RANKL and impeding that it binds to RANK. Therefore, the relative concentration of RANKL and $O P G$ in the bone is a factor determining its mass and strength 
(10). Recent study, demonstrated that the polymorphism rs3826620 in RANK is associated with the mandibular size (11). Although the three ligands RANK, RANKL and $O P G$ are the major modulators of bone apposition and resorption, $T N F-\alpha$ can modulate the biological activities of this triad (12)

Functional polymorphisms in the $T N F-\alpha$ gene could influence the self-amplification cycle of osteoclastogenesis, in which TNF- $\alpha$ induces more osteoclasts and its precursors, which in turn produce more TNF- $\alpha$ for formation of more osteoclasts and so on. The positive hypothesis of this study is that polymorphisms in TNF- $\alpha$ genes are involved in the etiology of skeletal class II malocclusion.

\section{Material and Methods}

\section{Subject Screening}

The Human Ethics Committee of Antônio Pedro Hospital of Fluminense Federal University (Protocol \#811.473) approved this study. Informed consent was obtained from all participating individuals or parents/legal guardians.

The study was conducted in Rio de Janeiro, in the south east region of Brazil, during the period of Jan 2015 to May 2016 (16 months). A total of 181 patients were enrolled in this study from Straight Wire Group of Studies on Orthodontics and Functional Orthopedics for Maxillae from Rio de Janeiro, Brazil.

The groups were divided from these subjects based on pre-established characteristics: skeletal class II malocclusion $\left(A N B>4^{\circ}\right)$ and skeletal class I malocclusion $(0<\mathrm{ANB}<4)$.

A sub group analysis was also performed based on preestablished characteristics: maxila protrusion $\left(\mathrm{SNA}>82^{\circ}\right)$ and maxila retrusion $\left(\mathrm{SNA}<82^{\circ}\right)$; mandible protrusion $\left(\mathrm{SNB}>80^{\circ}\right)$ and mandible retrusion $\left(\mathrm{SNB}<80^{\circ}\right)$.

Exclusion criteria for both groups comprised: orthopedic, orthodontic and/or surgical treatment performed prior to initial cephalometric tracing; presence of syndromes and/or metabolic and endocrine alterations, history of pathological processes such as tumors, cysts and/or trauma to facial bones (with potential to cause changes in the normal pattern of craniofacial growth and development), poor quality of radiographic records, parents/guardians who did not authorize the child's participation in the study and improperly filled out questionnaires.

\section{Cephalometric Analysis}

The cephalometric radiographs were digitalized with a HP scanner Scanjet G4050 and the resulting images transferred to the Atlante Software. One investigator was responsible for performing all measurements and radiographic interpretation.
The following radiographic measurements were evaluated on the patients: sella-nasion-A-point angle (SNA), sella-nasion-B-point angle (SNB), A-point-nasionB-point angle (ANB). In order to evaluate reliability and minimize variability all measurements were performed on fifty pacients and repeated on a different day following primary analysis.

\section{Single Nucleotide Polymorphism Genotyping}

Genomic DNA was obtained from saliva samples, as previously described. (13). The amount and purity of the DNA was determined by the spectrophotometer (Nanodrop ${ }^{\circledR}$ 1000; Thermo Scientific, Wilmington, DE, USA). Only DNA samples presenting A260nm/A280nm ratio greater than 1.8 were used. All examiners at the laboratories were blinded to the group assignment. SNPs were selected within TNF $\alpha$ (rs1799724; rs1800629) genes. Genotype were performed by real time polymerase chain reactions using the Taq Manassayin the Agilent Technologies (Stratagene Mx3005P). Applied Biosystems supplied the primers, probes and the universal mastermix (Foster City, CA, USA).

\section{Statistical Analysis}

Data were analyzed using the Statistical Package for the Social Sciences (SPSS 19.0). The Student's test and Pearson chi-square were used to analyze variables between class II and class I groups. PLINK ${ }^{\circledR}$ software was used to evaluate if groups presented preferential genotype and all allele associations in a free model, in a dominant model and recessive model. Values of $p<0.05$ were considered statistically significant. Hardy-Weinberg equilibrium was evaluated using Pearson chi-square with in each polymorphism and only the results that were in Hardy-Weinberg equilibrium were further analyzed. A Hardy-Weinberg in equilibrium would indicate there is not a genetic bias in the sample.

\section{Results}

Seventy-nine class II subjects and 102 class I subjects were included. Differences in mean age, sex and ethnicity between skeletal class II malocclusion and skeletal class I malocclusion subjects were not statistically significant (Table 1).

For both polymorphisms, the distribution of genotypes was consistent with Hardy-Weinberg equilibrium (data not shown). Table 2 demonstrates the genotype and allele distribution between skeletal class I and skeletal class II malocclusion groups. There was no statistical significance difference between the groups ( $p>0.05$ ). Table 3 presents the genotypic and allele distribution according to the subgroup of class II malocclusion. 


\section{Discussion}

Skeletal class I malocclusion represents the most common skeletal discrepancy of the dental arches seen in clinical dental practice. To the best of our knowledge this is the first report that investigates gene polymorphisms in TNF $\alpha$ and their relationshipin the etiology of skeletal class II malocclusion and retrognathism.

The role of genes involved in the development and establishment of skeletal class II malocclusion remains largely unknown. Both genetic and environmental factors play a role in craniofacial development, creating an intricate and elaborate multifactorial etiology for this

Table 1. Characteristics of the studied sample

\begin{tabular}{lccc}
\hline Characteristics & Class II $(\mathrm{N}=79)$ & Class I $(\mathrm{N}=102)$ & $\mathrm{p}$ value* \\
\hline Mean Age (SD) & $23.18(8.97)$ & $25.29(11.73)$ & 0.185 \\
Sex (\%) & & & \\
Male & $28(35.44)$ & $36(35.29)$ & 0.983 \\
Female & $51(64.56)$ & $66(64.71)$ & \\
\hline
\end{tabular}

Note: $p \leq 0.05$

Table 2. Genotype frequencies of TNFa in Class II $(n=79)$ and Class I individuals $(n=102)$

\begin{tabular}{|c|c|c|c|c|c|}
\hline & & Class I & Class II & OR (95\%CI) & $\mathrm{p}$ value \\
\hline \multicolumn{6}{|c|}{$T N F \alpha$ rs $1799724 T / C$} \\
\hline \multirow{2}{*}{ Genotype } & CT & 09 (11.11) & $03(5.45)$ & \multirow{2}{*}{$2.17(0.56-8.40)$} & \multirow{2}{*}{0.254} \\
\hline & $\mathrm{CC}$ & 72 (88.89) & $52(94.55)$ & & \\
\hline \multirow{2}{*}{ Allele } & C & 153 (94.44) & 107 (97.27) & \multirow{2}{*}{$0.48(0.13-1.80)$} & \multirow{2}{*}{0.265} \\
\hline & $\mathrm{T}$ & $09(5.56)$ & $03(2.73)$ & & \\
\hline \multirow{2}{*}{ Dominant Model } & $\mathrm{TT}+\mathrm{CT}$ & 09 (11.11) & 03 (5.45) & \multirow{2}{*}{$2.17(0.56-8.40)$} & \multirow{2}{*}{0.254} \\
\hline & $\mathrm{CC}$ & 72 (88.89) & $52(94.55)$ & & \\
\hline \multirow{2}{*}{ Recessive Model } & TT & $00(0)$ & $00(0)$ & \multirow{2}{*}{ Undefined } & \multirow{2}{*}{-} \\
\hline & $\mathrm{CT}+\mathrm{CC}$ & $81(100)$ & $55(100)$ & & \\
\hline \multicolumn{6}{|c|}{$T N F \alpha \operatorname{rs} 1800629 \mathrm{~A} / \mathrm{G}$} \\
\hline & AA & $01(1.15)$ & $00(0)$ & \multirow{3}{*}{-} & \multirow{3}{*}{0.208} \\
\hline \multirow[t]{2}{*}{ Genotype } & AG & $17(19.54)$ & $22(30.14)$ & & \\
\hline & GG & $69(79.31)$ & $51(69.86)$ & & \\
\hline \multirow{2}{*}{ Allele } & A & $19(10.92)$ & $22(15.07)$ & \multirow{2}{*}{$0.69(0.36-1.34)$} & \multirow{2}{*}{0.269} \\
\hline & G & 155 (89.08) & $124(84.93)$ & & \\
\hline \multirow{2}{*}{ Dominant Model } & $\mathrm{AA}+\mathrm{AG}$ & $18(20.69)$ & $22(30.14)$ & \multirow{2}{*}{$0.60(0.29-1.24)$} & \multirow{2}{*}{0.169} \\
\hline & GG & $69(79.31)$ & $51(69.86)$ & & \\
\hline \multirow{2}{*}{ Recessive Model } & AA & $01(1.15)$ & $00(0)$ & \multirow{2}{*}{ Undefined } & \multirow{2}{*}{0.358} \\
\hline & $\mathrm{AG}+\mathrm{GG}$ & $86(98.85)$ & $73(100)$ & & \\
\hline
\end{tabular}

$\mathrm{p} \leq 0.05$; OR (95\% C.I.)=0dds ratios; 95\% confidence intervals. malocclusion. Several researches have demonstrated that genetics account for maxillary and mandibular deficiencies in animals $(14,15)$. A study in mice demonstrated that TNF- $\alpha$, together with co-factors such as TGF- $\alpha$, can induce the formation of osteoclasts from hematopoietic precursors of RANK and RANKL (16). Another study, observed that mice deficient in RANKL and RANK do not form osteoclasts properly and have thickened hypertrophic cartilage zones in their growth plates. These knockout mice are dwarfed, suggesting that RANK and RANKL signaling during the early stages of life are essential for attainment of full skeletal growth (10). A previous study also demonstrated that members of the TNF superfamily: RANK and OPG are involved in mandible development (17). These previous results suggested potential candidate genes for the etiology of skeletal class II malocclusion and retrognathism. Along these lines, it is important to emphasize that animal model is a common strategy for the identification of candidate genes to a developmental alteration in humans.

Although the rapid progress in molecular biology is providing new information about the control of jaws growth and development, the evaluation in humans was limited performed. This highlights the importance of genetics studies with humans samples to understand the genetic background involved in the etiology of the class II malocclusion and the possible polymorphisms associated with this alteration.

In our study we decide to explore TNF- $\alpha$ as a candidate gene due itsimportant function in bone development (9). The TNF- $\alpha$ gene is located in the short arm of chromosome 6 , in the class III region of the major histocompatibility complex (MHC), and consists of four exons and three introns (18). TNF- $\alpha$ is a proinflammatory cytokine that acts in the regulation of cell proliferation, differentiation, and apoptosis (19). TNF- $\alpha$ and IL-1, are able to modulate the biological activities of the triad OPG/ RANK/RANKL. This triad is the main modulator of bone apposition/resorption coupling 
and should be considered as an osteoimmunomodulator complex (11). Despite this participation, our present results did not show a significant association with skeletal class II malocclusion or the position of the maxilla and mandible in the postero-anterior direction in terms of genotype or allele distributions. Indeed, several genetic factors probably play different roles in the self-amplification cycle of crescentshaped osteoclasts.

It is important to highlight that skeletal class II malocclusion is a general morphological description of a diverse group of dentofacial alterations, which presents a complex and unexplored etiology. The phenotype of class II malocclusion could involve maxillar protrusion, mandibular retrusion or a combination of both conditions. We were able to note that the studied polymorphism were not involved in maxilla neither mandible dimensions.

Despite having found no genetic predisposition associated with this malocclusion, the authors believe that further analyzes should be performed to confirm or refute the results found. In order to investigate the central role of this pathway skeletal class II malocclusion, further studies analyzing using distinct models and populations in a bigger sample size should be encouraged. The knowledge about genes and polymorphisms involved in the etiology of these conditions may be used as an additional tool to predict the establishment of a specific malocclusion phenotype as well as help to guide future orthodontic therapeutic approaches that may target periods of growth and development and prevent the need of extensive treatment approaches in a near future. Experimental studies may also help to confirm or refute the present findings.

So, there is no evidence that the risk of skeletal class II malocclusion or the position of the maxilla and mandible in the postero-anterior direction is influenced by genetic

Table 3. Genotype frequencies of TNFa according to position of the maxilla and mandible in the postero-anterior direction

\begin{tabular}{|c|c|c|c|c|c|c|c|c|c|}
\hline & & $\begin{array}{c}\text { Maxilla } \\
\text { protrusion } \\
97(\%) \\
\end{array}$ & $\begin{array}{c}\text { Maxilla } \\
\text { retrusion } \\
84(\%)\end{array}$ & OR $(95 \% \mathrm{CI})$ & $p$ value & $\begin{array}{c}\text { Mandible } \\
\text { protrusion } \\
\mathrm{N}(\%)\end{array}$ & $\begin{array}{c}\text { Mandible } \\
\text { retrusion } \\
\mathrm{N}(\%)\end{array}$ & OR (95\%CI) & $p$ value \\
\hline \multicolumn{10}{|c|}{$T N F \alpha$ rs $1799724 T C$} \\
\hline \multirow[b]{2}{*}{ Genotype } & CT & $08(11.27)$ & $04(6.15)$ & \multirow[b]{2}{*}{$1.94(0.55-6.76)$} & \multirow[b]{2}{*}{0.294} & 07 (12.96) & $05(6.10)$ & \multirow[b]{2}{*}{$2.29(0.69-7.64)$} & \multirow[b]{2}{*}{0.167} \\
\hline & $\mathrm{CC}$ & $63(88.73)$ & 61 (93.85) & & & $47(87.04)$ & 77 (93.90) & & \\
\hline \multirow{2}{*}{ Allele } & C & $134(94.37)$ & $126(96.92)$ & \multirow{2}{*}{$0.53(0.16-1.81)$} & \multirow{2}{*}{0.305} & $101(93.52)$ & 159 (96.95) & \multirow{2}{*}{$0.45(0.14-1.47)$} & \multirow{2}{*}{0.177} \\
\hline & $\mathrm{T}$ & $08(5.63)$ & $04(3.08)$ & & & $07(6.48)$ & $05(3.05)$ & & \\
\hline \multirow{2}{*}{$\begin{array}{l}\text { Dominant } \\
\text { Model }\end{array}$} & $\mathrm{TT}+\mathrm{CT}$ & 08 (11.27) & $04(6.15)$ & \multirow{2}{*}{$1.94(0.55-6.76)$} & \multirow{2}{*}{0.294} & 07 (12.96) & $05(6.10)$ & \multirow{2}{*}{$2.29(0.69-7.64)$} & \multirow{2}{*}{0.167} \\
\hline & $\mathrm{CC}$ & 63 (88.73) & 61 (93.85) & & & $47(87.04)$ & 77 (93.90) & & \\
\hline \multirow{2}{*}{$\begin{array}{l}\text { Recessive } \\
\text { Model }\end{array}$} & TT & $00(0)$ & $00(0)$ & \multirow{2}{*}{ Undefined } & \multirow{2}{*}{ - } & $00(0)$ & $00(0)$ & \multirow{2}{*}{ Undefined } & \multirow{2}{*}{-} \\
\hline & $\mathrm{CT}+\mathrm{CC}$ & 71 (100) & 65 (100) & & & $54(100)$ & $82(100)$ & & \\
\hline \multicolumn{10}{|c|}{$T N F \alpha \operatorname{rs} 1800629 \mathrm{~A} / \mathrm{G}$} \\
\hline & AA & $00(0)$ & $01(1.37)$ & \multirow{3}{*}{-} & \multirow{3}{*}{0.533} & $00(0)$ & $01(1.03)$ & \multirow{3}{*}{ - } & \multirow{3}{*}{0.608} \\
\hline \multirow[t]{2}{*}{ Genotype } & $A G$ & $22(25.29)$ & 17 (23.29) & & & 17 (26.98) & $22(22.68)$ & & \\
\hline & GG & $65(74.71)$ & $55(75.34)$ & & & 46 (73.02) & 74 (76.29) & & \\
\hline \multirow{2}{*}{ Allele } & A & $22(12.64)$ & $19(13.01)$ & \multirow{2}{*}{$0.97(0.50-1.87)$} & \multirow{2}{*}{0.921} & 17 (13.49) & $24(12.37)$ & \multirow{2}{*}{$1.10(0.57-2.15)$} & \multirow{2}{*}{0.769} \\
\hline & G & $152(87.36)$ & 127 (86.99) & & & 109 (86.51) & $170(87.63)$ & & \\
\hline \multirow{2}{*}{$\begin{array}{l}\text { Dominant } \\
\text { Model }\end{array}$} & $\mathrm{AA}+\mathrm{AG}$ & $22(25.29)$ & $18(24.66)$ & \multirow{2}{*}{$1.03(0.50-2.12)$} & דבח0 & 17 (26.98) & $23(23.71)$ & & $0 r \Omega 0^{\circ}$ \\
\hline & GG & $65(74.71)$ & 55 (75.34) & & 0.521 & 46 (73.02) & 74 (76.29) & $1.15(0.31-2.40)$ & 0.040 \\
\hline Recessive & AA & $00(0)$ & $01(1.37)$ & U d f & קדת & $00(0)$ & $01(1.03)$ & & \\
\hline Model & $\mathrm{AG}+\mathrm{GG}$ & 87 (100) & 72 (98.63) & - & 0.215 & 63 (100) & 96 (98.97) & - & 0.415 \\
\hline
\end{tabular}


polymorphisms involving TNF- $\alpha$.

\section{Resumo}

0 desenvolvimento e crescimento ósseo é um processo contínuo, que dura toda a vida, variando muito entre os individuos e grande parte dessa variação pode ser modulada por fatores genéticos. 0 objetivo deste estudo foi avaliar a associação entre os polimorfismos no gene TNF- $\alpha$ e a má oclusão da classe Il esquelética. Polimorfismos no gene TNF- $\alpha$ (rs1799724; rs1800629) foram estudados em 79 indivíduos com má oclusão esquelética de classe II e 102 indivíduos com má oclusão esquelética classe I do Grupo de Estudos em Ortodontia e Ortopedia Funcional dos Maxilares do Rio de Janeiro, Brasil. A genotipagem destes polimorfismos foi realizada por PCR em tempo real, através de DNA genômico extraído de células bucais. Todas as frequências alélicas e genotípicas foram comparadas entre os grupos utilizando o software PLINK ${ }^{\circledR}$ em um modelo livre, dominante e recessivo. Foi aplicado o teste do qui-quadrado $(p \leq 0,05)$. Não houve associação significativa na distribuição genotipica e alélica do gene TNF- $\alpha$ (rs1799724; rs1800629) com a má oclusão de classe Il esquelética. Independentemente do modelo genético dominante ou recessivo, as associações genotípicas preferenciais para rs1799724 e rs1800629 foram insignificantes. Podese concluir que, não existe evidência de associação entre polimorfismos genéticos envolvendo TNF- $\alpha$ e má oclusão esquelética de classe II ou a posição da maxila e mandibula na direção póstero-anterior.

\section{Acknowledgements}

We are indebted to the participants of the study. Support for this work was provided by Fundação Carlos Chagas Filho de Amparo à Pesquisa do Estado do Rio de Janeiro (FAPERJ) and Pró-Reitoria de Pesquisa, Pós-Graduação e Inovação / Plano de Desenvolvimento Institucional / Universidade Federal Fluminense (PROPPI/PDI/UFF) and FAPESP (ECK). authorship and/or publication of this article.

\section{References}

1. Nie X. Cranial base in craniofacial development: developmental features, influence on facial growth, anomaly, and molecular basis. Acta Odontol Scand 2005;63;127-135.

2. Chin A, Perry $S$, Liao $C$, Yang Y. The relationship between the cranial base and jaw base in a Chinese population. Head Face Med 2014;16;10:31.

3. Moyers RE, Elgoyhen JC, Riolo ML, McNamara JA Jr, Kuroda T. Experimental production of Class III in Rhesus monkeys. Rep Congr Eur Orthod Soc1970;46;61.

4. Steiner CC. A Cephalometrics for you and me. Amer J Orthodontics1953;39;729-755.
5. Khoja A, Fida M, Shaikh Cephalometric evaluation of the effects of the Twin Block appliance in subjects with Class II, Division 1 malocclusion amongst different cervical vertebral maturation stages. Dental Press J Orthod 2016;21;73-84.

6. Vargervik K, Harvold EP. Response to activat or treatment in Class II malocclusions. Am J Orthod 1985;88;242-251.

7. Mossey PA. The heritability of malocclusion: part 2. The influence of genetics in malocclusion. Br J Orthod 1999;26;195-203.

8. Clarke B. Normal bone anatomy and physiology. Clin J Am Soc Nephrol 2008;3;131-139.

9. Horowitz MC, Xi Y, Wilson K, Kacena MA. Control of osteoclastogenesis and bone resorption by members of the TNF family of receptors and ligands. Cytokine Growth Factor Rev 2001;12;9-18.

10. Boyce BF, Xing L. Functions of RANKL/RANK/OPG in bone modeling and re modeling. Arch Biochem Biophys 2008;473;139-146.

11. Küchler EC, Nascimento MAD, Matsumoto MAN, Romano FL, da Silva RAB, Ayumi Omori M1, et al. Genetic polymorphism in RANK is associated with mandibular size. J Orthod 2018;25:1-6.

12. Theoleyre $S$, Wittrant $Y$, Tat SK, Fortun $Y$, Redini F, Heymann D. The molecular triad OPG/RANK/RANKL: involvement in the orchestration of pathophysiological bone remodeling. Cytokine Growth Factor Rev 2004;15,457-475.

13. Küchler EC, Tannure PN, Falagan-Lotsch $\mathrm{P}$, Lopes TS, Granjeiro JM, Amorim LM. Buccal cells DNA extraction to obtain high quality human genomic DNA suitable for polymorphism genotyping by PCR-RFLP and Real-Time PCR. J Appl Oral Sci 2012;20;467-471.

14. Dudas M, Kim J, Li WY, Nagy A, Larsson J, Karlsson S, et al. Epithelial and ectomesenchymal role of the type I TGF-beta receptor ALK5 during facial morphogenesis and palatal fusion. Dev Biol 2006;296;298-314.

15. Oka K, Oka S, Sasaki T, Ito Y, Bringas P Jr, Nonaka K, et al. The role of TGF-beta signaling in regulating chondrogenesis and osteogenesis during mandibular development. Dev Biol 2007;303;391-404.

16. Kim N, Kadono Y, Takami M, Lee J, Lee SH, Okada F, et al. Osteoclast differentiation independent of the TRANCE-RANK-TRAF6 axis. J Exp Med 2005;202;589-595.

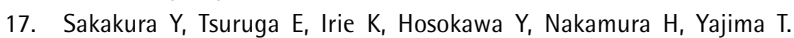
Immunolocalization of receptor activator of nuclear factor-kappaB ligand (RANKL) and osteoprotegerin (OPG) in Meckel's cartilage compared with developing endochondral bones in mice. J Anat 2005;207;325-337.

18. Makhatadze NJ. Tumor necrosis factor locus: genetic organisation and biological implications. Hum Immunol1998;59;571-579.

19. Brenner $D$, Blaser $H$, Mak TW. Regulation of tumour necrosis factors signalling: live or let die. Nat Rev Immunol 2015;15;362-374.

Received June 18, 2018 Accepted September 24, 2018 